AN INTERNATIONAL JOURNAL

\title{
Clinostomum complanatum (Digenea, Clinostomidae) Density in Rhamdia quelen (Siluriformes, Pimelodidae) from South Brazil
}

\author{
Rogério Tubino Vianna ${ }^{1}$, Joaber Pereira Júnior ${ }^{2 *}$ and Deodoro Atlante Brandão ${ }^{3}$ \\ ${ }^{1}$ Programa de Pós-Graduação em Zoologia; Universidade Federal do Paraná; C. P. 19020; 81531-980; \\ rtvianna@yahoo.com.br; Curitiba - PR - Brasil. ${ }^{2}$ Departmento de Ciências Morfobiológicas; Fundação \\ Universidade Federal do Rio Grande; C. P. 474; 96650-900; dmbjpj@furg.br; Rio Grande - RS - Brasil. \\ ${ }^{3}$ Departamento de Zootecnia; Universidade Federal de Santa Maria; 97105-900; sai@adm.ufsm.br; Santa Maria - \\ RS - Brasil
}

\begin{abstract}
The density of Clinostomum complanatum metacercariae by the body regions and among the size classes of Rhamdia quelen was compared. The host size classes were defined by cluster analysis, using weight and total length as attributes. These values were related with environmental characteristics and host biological data. In all the host size classes $H$ and $P e F, C F$ and $P F$, and $P$ and $A F$ regions pairs, showed similar density (tested by $X^{2}$ test). The hosts with 30-36 cm showed largest parasite density in all the regions, except in CAV. Fishes smaller than $11 \mathrm{~cm}$ did not show significant differences of parasite density in all body regions. In the other classes, $H$ was the most infected region, followed by PeF. The results suggested that the environmental conditions had little importance on the host colonization by metacercariae.
\end{abstract}

Key words: Clinostomum complanatum, Rhamdia quelen, metacercariae density, Jundiá, South Brazil, fish disease, aquaculture

\section{INTRODUCTION}

The South American Catfish, Rhamdia quelen (Quoy and Gaimard, 1824) (Siluriformes, Pimelodidae) has importance for the pisciculture (Kossowski, 1996) and is found in South and Central America (Silfvergrip, 1996). This fish prefers the muddy bottom covered by leaves and decaying wood that provide protection during the day, and eat on benthic crustacean and zooplankton (Le Bail et al., 2000). R. quelen has a benthic behaviour (Guedes, 1980; Grosser et al., 1994; Bizerril, 1998; Bizerril and Lima, 2000) which facilitate the Digenea recruitment (Eiras et al., 1999, Guzmán-Cornejo and García-Prieto, 1999). Clinostomum complanatum (Rudolphi, 1814) Braum, 1899 (Clinostomidae) metacercariae infect the skin, muscle, fins, head and viscera, causing pathologies and changes in the host behavior, with consequent economic losses in fish farms (Kagei et al., 1984; Eiras, 1994; Mitchell, 1995). The Clinostomum infection increases with the host size, suggesting a cumulative process (Kalantan et al., 1987).

\footnotetext{
${ }^{*}$ Author for correspondence
} 


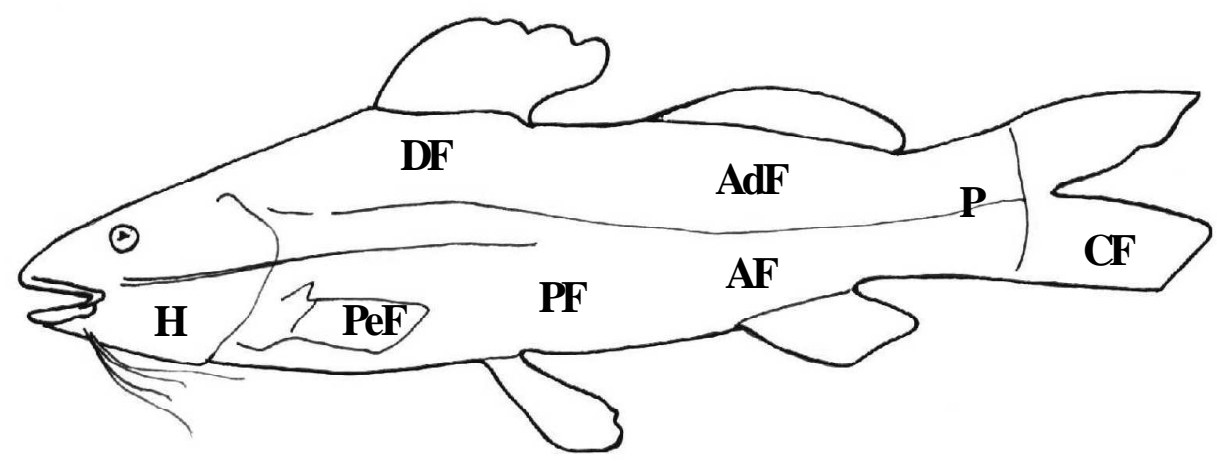

Figure 1 - Body regions of Rhamdia quelem used for the density calculation of Clinostomum complanatum metacercárias. AdF - Adipose fin; AF - Anal fin; CF - Caudal fin; DF - Dorsal fin; H - Head; P - Peduncle; PeF Pectoral fin; PF - Pelvic fin.

The site of infection is the place in the host body that provides the requirements of the parasite. The occupied site by the parasite in each life cycle stages depends of the type of immediately anterior stage, and the location of the metacercariae will depend on the behavior pattern showed by cercariae (Erasmus, 1972).

In this study the distribution of $C$. complanatum metacercariae infrapopulations in the body regions of $R$. quelen of Southern Brazil was defined in distinct host size classes. These results were confronted with the host ontogenetic changes and its environment distribution in order to establish if environmental conditions influenced the host colonization by the metacercariae.

\section{MATERIALS AND METHODS}

One hundred and twenty specimens of Rhamdia quelen, caught in the Sarandí stream $\left(32^{\circ} 00^{\prime}\right.$ $32^{\circ} 10^{\prime} \mathrm{S}$ and $32^{\circ} 20^{\prime}-32^{\circ} 30^{\prime} \mathrm{W}$ ) in Rio Grande, Rio Grande do Sul State, Brazil, between September 1999 and August 2000 were examined in order to determine parasitological index of Clinostomum complanatum metacercariae. For necropsy, each host body was divided in nine regions: Head $(\mathrm{H})$, Pectoral fin (PeF), Dorsal fin (DF), Adipose fin (AdF), Caudal Peduncle (P), Caudal fin (CF), Anal fin $(\mathrm{AF})$, Pelvic fin (PF), Abdominal cavity (CAV) (Fig. 1). The density values (sensu Bush et al., 1997) of C. complanatum by host body regions were compared among and inside each size class using the chi-square test.

The definition of the host size classes limits was assayed in two ways: Initially by using the Sturgers equations $(\mathrm{K}=1+3.3 \mathrm{x} \log \mathrm{n})$ and total width $(\mathrm{h}=$ higher length value - smaller length value / K) (Arango, 2001), which resulted eight host size classes. In the second assay, weight (g) and total length $(\mathrm{cm})$ mean values of the eight classes obtained with Sturgers equation were used as attributes in the non-parametric Cluster analysis (Ward Method - Euclidian distance) (Arango, 2001). With this, dendrograms with 5, 6 and 7 size classes were created (Table 3 ). To determine the best dendrogram, relationships were established with the host biology ( $R$. quelen or similar cogeneric species when necessary) and with space distribution using available dates on the environmental (Table 1 and Fig. 2). The importance and discriminatory capacity of each attribute for cluster definition was obtained by " $\mathrm{K}$ - means" algorhytm, that was used to eliminate tendentious definition in its composition (Digbby and Kempton, 1991).

\section{RESULTS}

Among 120 examined fishes, 77 were infected with a total of 17777 C. complanatum metacercariae. The 7 size classes dendrogram was adopted because showed the best relationship with 
host biological and environmental host distribution features (Fig 2). The first sexual maturation length and largest frequencies sizes (Table 1) were determinants for the separation of 3-7 size classes hosts that occurred in the area III (Table 2 and line c from Fig. 2). The general density of $C$. complanatum showed significant differences both between and within the different $R$. quelen size classes. The density values of $C$. complanatum showed no significant differences in all host size classes at the following pairs of body regions: $\mathrm{H}$ and PeF; $\mathrm{CF}$ and VF; $\mathrm{P}$ and $\mathrm{AF}$. The size class 5 shows higher density in all regions, except in CAV (Table 4) and AF. The size class 5 shows higher density in all regions, except in CAV (Table 4). The density into each size class did not show significant difference in class 1 in all host body regions. In the others classes, there were differences and $\mathrm{H}$ showed higher densities values, followed by PeF (Table 4).

\section{DISCUSSION}

Mardini et al. (1981) observations showed that host class 1 was observed only in area I (Table 2 and Fig. 2) corroborating these results. Although shallow and with little current places, the area I showed low transparency. These features could favor fish larvae survival, as reported by Behr et al. (1999) and also favored the infection by $C$. complanatum, since its cercariae swimmer actively (Eiras et al., 1999).

However, the smallest infection values (absolute and relative) were observed in the size class 1 .

The class 2 hosts were collected in the area II and the differences of environmental features were related with changes in alimentary habit (Guedes, 1980) and alterations of host reproductive behavior (Narahara et al., 1985) (Table 1). The influence of the first sexual maturation length and the largest frequencies sizes on the distribution of $R$. quelen in the Sarandí stream was similar to observations move by Arratia (1983) who showed Siluriformes environmental distribution changing with their growth. In the present study, $C$. complanatum density in $R$. quelen was largest in the head region, especially in the oro-branchial cavity. In Aphanius dispar (Cyprinodontidae) the largest density of these metacercariae was found in the trunk, followed by the head and tail (Kalantan et al., 1987).

Table 1 - Relationships among frequency space distribution and others host biology available data (especially reproduction) of Rhamdia quelen or similar cogeneric species when necessary (ND = numbers in line D of Fig. 2).
ND
Features
Reference

\begin{tabular}{|c|c|c|}
\hline 1 & $\begin{array}{l}\text { R. quelen spawns and reproduces at places with low transparency and } \\
\text { little current. Fingerlings and juveniles stay at these places }\end{array}$ & $\begin{array}{l}\text { Mardini et al., (1981); } \\
\text { Behr et al., (1999) }\end{array}$ \\
\hline 2 & $\begin{array}{l}\text { Males of } R \text {. hilarii with } 11-13 \mathrm{~cm} \text { more frequent (Jaguarí river, SP, } \\
\text { 1973-1975). }\end{array}$ & Narahara et al., (1985) \\
\hline 3 & $\begin{array}{l}\text { First maturation }(\mathrm{L} 50) \text { of males }(14 \mathrm{~cm}) \text { and females }(13 \mathrm{~cm}) \text { in } R \text {. } \\
\text { hilarii. }\end{array}$ & Narahara et al., (1985) \\
\hline 4 & $\begin{array}{l}\text { Total maturation }(\mathrm{L} 100) \text { in males }(16 \mathrm{~cm}) \text { and females }(17 \mathrm{~cm}) \text { in } R \text {. } \\
\text { hilarii. }\end{array}$ & Narahara et al., (1985) \\
\hline 5 & Males of R. hilarii with $17-23 \mathrm{~cm}$. (1973-1974). & Narahara et al., (1985) \\
\hline 6 & Male predominance of $R$. hilarii with length between 25 and $27 \mathrm{~cm}$. & Narahara et al., (1985) \\
\hline 7 & Larger weight in males of $R$. quelen, Santa Catarina swamp, RS. & Weis (1983) \\
\hline 8 & Higher frequencies of males $(34 \mathrm{~cm})$ and females $(32 \mathrm{~cm})$. & Weis (1983) \\
\hline 9 & $\begin{array}{l}\text { Larger total length of males of } R \text {. quelen }(33 \mathrm{~cm}) \text { and females }(56 \\
\mathrm{cm}) \text {. }\end{array}$ & $\begin{array}{l}\text { Garro and Fialho } \\
\text { (1997) }\end{array}$ \\
\hline
\end{tabular}


Table 2 - Characterization of collection areas in the Sarandí stream, Rio Grande, RS, Brazil, station occurrence and the size classes of Rhamdia quelen (line E of Fig. 2).

\begin{tabular}{|c|c|c|}
\hline Area & Features & $\begin{array}{c}\text { Collected classes } \\
\text { (annual occurrence) }\end{array}$ \\
\hline I & $\begin{array}{l}\text { Flooded area between November/1999 and March } / 2000(30-50 \mathrm{~cm} \\
\text { depth) on both banks. Creeping submerged vegetation (especially } \\
\text { Graminae). Low transparency and current, } 26-28^{\circ} \mathrm{C} \text { (Dec.; Jan.; } \\
\text { Feb.- summer); } 23-27{ }^{\circ} \mathrm{C} \text { (Mar.; Ap.; May.- autumn) water } \\
\text { temperature. }\end{array}$ & $\begin{array}{c}1 \\
\text { (summer; autumn) }\end{array}$ \\
\hline II & $\begin{array}{l}\text { Burrow areas. }(40-80 \mathrm{~cm} \text { depth). Submerged and/or emerged } \\
\text { vegetation on the banks. Strong stream, little material in suspension; } \\
22-27^{\circ} \mathrm{C} \text { (Dec.; Jan.; Feb.- summer); } 23-27^{\circ} \mathrm{C} \text { (Mar.; Ap.; May.- } \\
\text { autumn) water temperature. }\end{array}$ & $\begin{array}{c}2 \\
\text { (summer; autumn) }\end{array}$ \\
\hline III & $\begin{array}{l}\text { Water column }(50-170 \mathrm{~cm} \text { depth) without fixed vegetation. Only } \\
\text { emerged fluctuant vegetation. Strong stream (?) and turbidity due to } \\
\text { suspension of sediment and organic matter. } 19-25^{\circ} \mathrm{C} \text { (spring); } 22- \\
28^{\circ} \mathrm{C} \text { (summer); } 20-24^{\circ} \mathrm{C} \text { (autumn); } 10-16^{\circ} \mathrm{C} \text { (winter) water } \\
\text { temperature. }\end{array}$ & $\begin{array}{l}3-7 \\
\text { (spring; summer; } \\
\text { autumn; winter) }\end{array}$ \\
\hline
\end{tabular}

Table 3 - Rhamdia quelen size class limits $(\mathrm{cm})$ obtained by Sturgers equation and by Cluster analysis. $\mathrm{N}=$ number of fish.

\begin{tabular}{ccccc}
\hline Class & Sturgers & $\mathbf{N}$ & Cluster & $\mathbf{N}$ \\
\hline 1 & $1.70-7.36$ & 29 & $1.70-7.36$ & 29 \\
2 & $7.37-13.02$ & 12 & $7.37-13.02$ & 12 \\
3 & $13.03-18.68$ & 5 & $13.03-24.35$ & 12 \\
4 & $18.69-24.35$ & 7 & $24.36-30.01$ & 28 \\
5 & $24.36-30.01$ & 28 & $30.02-35.67$ & 24 \\
6 & $30.02-35.67$ & 24 & $35.68-41.34$ & 11 \\
7 & $35.68-41.34$ & 11 & $41.35-47.00$ & 04 \\
8 & $41.35-47.00$ & 4 & - & - \\
\hline
\end{tabular}

This was due to the easiness found by the cercariae invading the sub-opercular tissue, distributing from there to other body regions. Metacercariae of C. marginatum from Loricariichthys platymetopon (Loricariidae), has larger intensity of infection in the buccal cavity and opercle (Eiras et al., 1999). In Amazon, Thatcher (1991) reported the infection by $C$. marginatum on the gills of Cichla ocellaris (Cichlidae) and in Crenicichla sp (Cichlidae). The data of Thatcher (1991), Eiras et al. (1999) and Kalantan et al. (1987), however, were not obtained with rigorous host body subdivision, as done in this study.

Besides the body regions already mentioned, cysts of $C$. complanatum were also observed in the barbels, opercle, branchoiostegal membranes, muscles, gills, palate, pharynx and eyes of $R$. quelen. Eiras et al. (1999) reported cysts in the ocular globule, which did not cause blindness. However, fish vision could be affected by the parasite. This would facilitate the predation by birds (the main final host of Clinostomum).

Most of the Digenea cysts occurred in the trunk, followed by in the fins, usually with larger movement, as caudal and pectoral (Erasmus, 1972), which also contradicted the common belief that these regions were difficult to the cercariae penetration in the host. Eiras et al. (1999) found low infection in the caudal fin and they attributed this to the constant movements of the anal fin. The $\mathrm{PeF}, \mathrm{AF}$ and $\mathrm{CF}$ regions in $R$. quelen showed the largest densities after $\mathrm{H}$, entering inside of each host size class and the largest densities were in the fins with larger movement (Erasmus, 1972). Holmes (1973) found that parasites with active infection processes selected its site, which was also observed in cercariae of $C$. complanatum by Krull (1934) and Paperna (1980).

The fact that the density values of $C$. complanatum observed in the pairs of body regions $\mathrm{H}$ and $\mathrm{PeF}$, $\mathrm{CF}$ and $\mathrm{PF}$ and $\mathrm{P}$ and $\mathrm{AF}$ were similar in all host 
size classes suggested that a pattern of site occupation occurred when they had similar environmental conditions. Furthermore, the fact that among the adults, class 5 was the most frequent in the environment (Table 3) and showed the highest metacercariae density in all body regions, except for CAV (Table 4) indicated higher densities than those observed contributing to the host mortality. Hence in these hosts were not detected. It was therefore, possible to suggest that the parasitosis influenced the structure of the host population.

Different sizes of metacercariae of $C$. complanatum are found in $R$. quelen, which may point to several subsequent recruitment processes and a cumulative infection. This idea was reinforced by Esch et al. (1975), who found that the parasitic density could be increased by recruitment when a reduction of natural or acquired resistance, elimination of ecological or behavior barriers, and seasonal changes of environmental conditions occurred.

Different sizes of $C$. complanatum metacercariae found in $R$. quelen can be evidenced in subsequent recruitment processes and a cumulative infection.
The parasitic density in the second intermediate hosts, as $R$. quelen to $C$. complanatum, could be increased by recruitment when a reduction of natural or acquired resistance, elimination of ecological or behavior barriers, and seasonal changes of environmental conditions occurred (Esch et al., 1975). The benthonic condition of $R$. quelen (Bizerril, 1998, Bizerril and Lima, 2000) can also facilitate the cercarial recruitment of $C$. complanatum (Eiras et al., 1999).

The density differences in the host size classes may be due to the several sizes of corporal surfaces, (Elliott and Russert, 1949, Kalantan et al., 1987). The consistently similar density values of $C$. complanatum observed in the pairs of body regions $\mathrm{H}$ and $\mathrm{PeF}, \mathrm{CF}$ and $\mathrm{PF}$ and $\mathrm{P}$ and $\mathrm{AF}$ in all the host size classes suggested that the differences in the host location in the environment had little influence on the body regions colonized by the metacercariae. However, as shown in Table 2, it was possible to conclude that as environmental segregation by the different host size classes occurred, the density differences could not be influenced exclusively by body size.

Table 4 - Comparison of Clinostomum complanatum density between size classes in the body regions (letters without parenthesis in the same column) and between body regions in the host size classes (letters in parenthesis in the same line) of Rhamdia quelen. H - Head; DF - Dorsal fin; AdF - Adipose fin; P - Peduncle; CF - Caudal fin; AF - Anal fin; PF - Pelvic fin; PeF - Pectoral fin; CAV- Abdominal cavity.

\section{Size classes $\quad$ Density by body region}

\begin{tabular}{|c|c|c|c|c|c|c|c|c|c|c|c|}
\hline & $\mathrm{H}$ & DF & $\mathrm{AdF}$ & & & $\mathrm{CF}$ & $\mathrm{AF}$ & $\mathrm{PF}$ & $\mathrm{PeF}$ & & CAV \\
\hline \multirow[t]{2}{*}{1} & 2 & 1 & 0 & & & 1 & 0 & 0 & 0 & & 0 \\
\hline & $\mathrm{G} \quad$ (A) & E (A) & F $\quad$ (A) & E & (A) & F (A) & E (A) & $\mathrm{F} \quad$ (A) & $\mathrm{G} \quad$ (A) & $\mathrm{D}$ & (A) \\
\hline \multirow[t]{2}{*}{2} & 24 & 4 & 0 & & & 5 & 1 & 2 & 9 & & 4 \\
\hline & $\mathrm{F} \quad$ (A) & $\mathrm{E} \quad(\mathrm{BC})$ & $\mathrm{F} \quad(\mathrm{C})$ & E & (C) & $\mathrm{F} \quad(\mathrm{BC})$ & E (C) & $\mathrm{F} \quad(\mathrm{C})$ & $\mathrm{F} \quad$ (B) & $\mathrm{C}$ & (BC) \\
\hline \multirow[t]{2}{*}{3} & 259 & 30 & 9 & & $t$ & 46 & 77 & 37 & 77 & & 2 \\
\hline & E $\quad$ (A) & $\mathrm{D} \quad$ (C) & E $\quad$ (D) & D & (D) & E $\quad$ (C) & D $\quad$ (B) & E $\quad$ (C) & E $\quad$ (B) & $\mathrm{CD}$ & (E) \\
\hline \multirow[t]{2}{*}{4} & 1605 & 410 & 136 & & & 546 & 754 & 414 & 1002 & & 28 \\
\hline & B $\quad$ (A) & B $\quad$ (D) & $\mathrm{C} \quad(\mathrm{F})$ & A & (E) & $\mathrm{CB} \quad(\mathrm{C})$ & BA $\quad$ (B) & B $\quad$ (D) & B $\quad$ (A) & A & (G) \\
\hline \multirow[t]{2}{*}{5} & 2344 & 559 & 224 & & & 624 & 804 & 567 & 1330 & & 8 \\
\hline & $\mathrm{A} \quad$ (A) & $\mathrm{A} \quad$ (D) & $\mathrm{A} \quad$ (E) & A & (F) & $\mathrm{A} \quad$ (D) & A $\quad$ (C) & $\mathrm{A} \quad$ (D) & A $\quad$ (B) & $\mathrm{BC}$ & (G) \\
\hline \multirow[t]{2}{*}{6} & 1208 & 289 & 181 & & & 302 & 409 & 268 & 533 & & 23 \\
\hline & C & C & B $\quad(\mathrm{E})$ & B & (F) & & B $\quad$ (C) & $\mathrm{C}$ & & $\mathrm{AB}$ & \\
\hline \multirow[t]{2}{*}{7} & 1001 & 263 & 49 & & & 138 & 204 & 177 & 276 & & 12 \\
\hline & $\mathrm{D} \quad$ (A) & $\mathrm{C} \quad$ (B) & $\mathrm{D} \quad(\mathrm{E})$ & C & (E) & $\mathrm{D} \quad$ (D) & C $\quad$ (C) & $\mathrm{D} \quad$ (C) & D $\quad$ (B) & B & (F) \\
\hline
\end{tabular}

When values are followed by different letters in the same line or in the same column $\mathrm{P}<0,05$. 


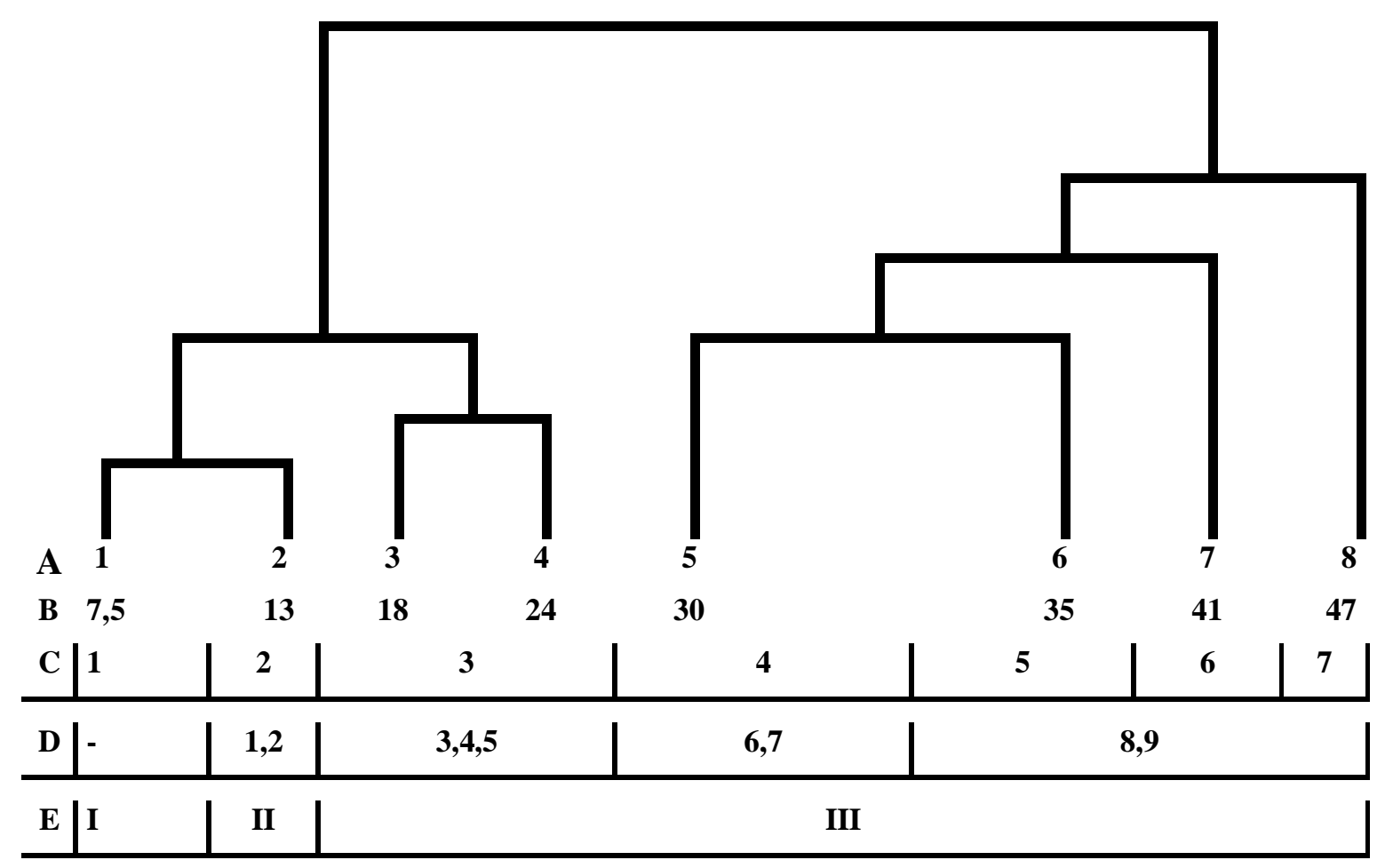

Figure 2 - Dendrogram for size classes (cm) of Rhamdia quelen and their relationships. ASize class obtained by Sturgers equation; B- Size class upper limits obtained by Sturgers equation; C-Distribution of the size classes obtained by cluster analysis; D - Distribution using features shown in Table 1; E - Distribution using features shown in Table 2.

The corporal volume of the parasites could condition the colonization pattern, and this could be a more determining parameter than indexes such as the density (George-Nascimento et al., 2002), but the observations in this study did not agree this. Previous studies have determined the specificity of parasite site of infection and the possibility of discarding parts to minimize fish carcass losses in the industry (Overstreet, 1977; Amato et al., 1990). The high densities and nonspecificity of infection site for metacercariae of $C$. complanatum in $R$. quelen make it possible to point that the selective discarding of parts of the fish carcass is not feasible.

\section{RESUMO}

A densidade de metacercárias de Clinostomum complanatum por regiões do corpo entre classes de comprimento de Rhamdia quelen foram comparadas. As classes de comprimento do hospedeiro foram definidas por analises de agrupamentos usando peso e comprimento total como atributos. Estes valores foram relacionados com características do ambiente e dados biológicos disponíveis sobre o hospedeiro. O dendrograma com sete agrupamentos foi $\mathrm{o}$ escolhido. $\mathrm{O}$ corpo do hospedeiro foi dividido em nove regiões para as necropsias: Cabeça $(\mathrm{H})$; Nadadeiras, Peitoral (PeF); Dorsal (DF); Adiposa (AdF); Caudal (CF); Anal (AF) e Pélvica (PF); Pedúnculo caudal (P); Cavidade Abdominal (CAV). Em todas as classes de comprimento do hospedeiro os pares de regiões $\mathrm{H}$ e PeF, $\mathrm{CF}$ e PF e $\mathrm{P}$ e AF mostraram densidades similares (teste do $\mathrm{X}^{2}$ ). Hospedeiros com $30-36 \mathrm{~cm}$ mostram maior densidade de parasitas em todas as regiões exceto na CAV. Peixes com menos de $11 \mathrm{~cm}$ não mostram diferenças significativas na densidade de parasitas nas regiões do corpo. Nas demais classes, $\mathrm{H}$ é a região mais infectada, seguida por PeF. Os resultados sugerem que as variáveis ambientais têm pouca importância sobre o processo de colonização por metacercárias. 


\section{ACKNOWLEDGEMENTS}

The authors are grateful to Dr. José H. da Silva (Departmento de Zootecnia - Universidade Federal de Santa Maria) for his statistical analysis assistance, to Dr. Paulo César Abreu (Departmento de Oceanografia- Fundação Universidade Federal do Rio Grande) for the critical review of the manuscript, to Valdir Ponciano for his assistance with host collection, to João Casimiro and Ieda Quadros (both from Fundação Universidade Federal do Rio Grande) for the slide preparation and Coordenação de Aperfeiçoamento de Pessoal de Nível Superior for supporting (to R. T. V.).

\section{REFERENCES}

Amato, J. F.; São Clemente, S. C. and Oliveira, G. A. (1990), Tentacularia coryphaenae Bosc, 1801 (Eucestoda: Trypanorhyncha) in the inspection and technology of the skipjack tuna, Katsuwonus pelamis (L.) (Pisces: Scombridae). Atlântica, 12, 73-77.

Arango, H. M. (2001), Bioestatística Teórica $e$ Computacional. Rio de Janeiro : Guanabara Koogan.

Arratia, G. F. (1983), Preferencias de habitat de peces siluriformes de aguas continentales de Chile (Fam. Diplomystidae y Trichomycteridae). Stud. Neotrop. Fauna Environ., 18, 217-237.

Behr, E. R.; Radünz Neto, J. and Tronco. A. P. (1999), Influência de diferentes níveis e luminosidade de larvas de jundiá (Rhamdia quelen) (Quoy and Gaimard, 1824) (Pisces: Pimelodidae). Acta Scient., 21, 325-330.

Bizerril, C. R. S. F. (1998), Comunidades de peixes do médio curso de sistemas fluviais da região carbonífera Sul-catarinense. I. Bacia do Rio Araranguá. Acta Biol. Leopold., 20, 225-242.

Bizerril, C. R. S. F.and Lima, N. R. W. (2000), Levantamento da ictiofauna da bacia do Rio Ribeira, Brasil. Acta Biol. Leopold., 22, 103-110.

Bush, A. O.; Lafferty, K. D.; Lotz, J. M. and Shostak, A. W. (1997), Parasitology meets ecology on its own terms: Margolis et al., revisited. J. Parasitol., 83, 575-583.

Digbby, P. G. N. and Kempton, R. A. (1991), Multivariate analysis of ecological communities. London : Chapman and Hill.

Eiras, J. C. (1994), Elementos de Ictioparasitologia. Fundação Eng. Ântonio de Almeida, Porto.

Eiras, J. C.; Dias, M. L.; Pavanelli, G. C. and Machado, M. (1999), Histological studies on the effects of Clinostomum marginatum (Digenea, Clinostomidae) in the second intermediate host Loricariichthys platymetopon (Osteichthyes, Loricariidae), of the upper Paraná River, Brazil. Acta Scient., 21, 237-241.
Elliott, A. M. and Russert, L. R. (1949), Some condition characteristic of a yellow perch population heavily parazited by Clinostomum marginatum. J. Parasitol., 35, 183-190.

Erasmus, D. A. (1972), The biology of Trematodes. London : Edward Arnold.

Esch, G. W.; Gibbons, W. and Bourque, J. E. (1975), An analysis of the relationship between stress and parasitism. Am. Midland Nat., 93, 339-353.

Garro, F. L. T. and Fialho, A. P. (1997). Estrutura populacional, Idade e Crescimento da Rhamdia quelen (Quoy and Gaimard, 1824) - Pisces, Siluriformes, Pimelodidae). Cadernos de Pesquisa da Univ. Cat. Goiás, 8, 1-52.

George-Nascimento, M.; Garcáis, F. and Muñoz, G. (2002), Parasite body volume and infracommunity patterns in the southern pomfret Brama australis (Pisces: Bramidae). Rev. Chil. Hist. Nat., 75, 835-839.

Grosser, K. M.; Koch, W. R. and Drügg-Hahn, S. (1994), Ocorrência e distribuição de peixes na estação ecológica do Taim, Rio Grande do Sul, Brasil (Pisces, Teleostomi). Iheringia, 77, 89-98.

Guedes, D. S. (1980), Contribuição ao estudo da sistemática e alimentação de jundiás (Rhamdia spp.) na região central do Rio Grande do Sul (Pisces: Pimelodidae). MSc Thesis, Universidade Federal de Santa Maria, Santa Maria, Brazil.

Guzmán-Cornejo, M. C. and García-Prieto, L. (1999), Trematodiasis en algunos peces del lago de Cuitzeo, Michoacán, México. Rev. Biol. Trop., 47, 593-596.

Holmes, J. C. (1973), Site selection by parasitic helminths: interspecific interactions, site segregation, and their importance to the development of helminth communities. Can. J. Zool., 51, 333-347.

Kagei, N., Yanohara, Y., Uchikawa, R. and Sato, A. (1984), On the yellow grubs, metacercariae of Clinostomum complanatum (Rudolphi, 1819), found in the cultured loach. Jpn. J. Parasit., 33, 59-62.

Kalantan, A. M.; Arfin, M. and Nizami, W. A. (1987), Seasonal incidence and pathogenicity of the metacercariae of Clinostomum. J. Parasitol., 36, 17-23.

Kossowski, C. (1996), Perspectives de’lélevage dês poissons-chats (Siluridei) em Amérique de Sud. Living Resour., 9, 189-195.

Krull, W. H. (1934), Some observations of the cercaria and redia of a species of Clinostomum, apparently $C$. marginatum (Trematoda: Clinostomidae). Proc. Helminthol. Soc. Wash., 1, 34-35.

Le Bail, P. Y.; Keith, P. and Planquette, P. (2000), Atlas de poissons d'eau douce de Guyane (Tome 2, Fascicule II). Paris : Publications Scientifique de MNHN. 
Mardini, C. V.; Silveira, M. A. and Barenho, D. H. L. (1981), Técnica de indução da desova em jundiá (Rhamdia quelen) empregada na estação experimental de piscicultura da Lagoa dos Quadros. Relatórios da Secretaria da Agricultura do Estado do Rio Grande do Sul - Departamento de Pesca, Porto Alegre, Brazil.

Mitchell, A. J. (1995), Yellow grubs and other problems associated with aquatic birds. Aquacult. Mag. 21, 93-97.

Narahara, M. Y., Godinho, H. M., Romagosa, E. (1985), Estrutura da população de Rhamdia hilarii (Valenciennes, 1840) (Osteichthyes, Siluriformes, Pimelodidae). Bol. Inst. Pesca, 12, 123-137.

Overstreet, R. M. (1977), Poecilancistrium caryophyllum and other trypanorhynch cestode plerocercoids from the musculature of Cynoscion nebulosus and other Sciaenid fishes in the gulf of Mexico. J. Parasitol. 63, 780-789.

Paperna, I. (1980), Parasites, infections and diseases of fish in Africa. In: FAO - CIFA Tech. Pap 7. Roma. pp. 79-85.

Silfvergrip, A. M. C. (1996), A systematic revision of the neotropical catfish genus Rhamdia (Teleostei, Pimelodidae). PhD Thesis, Stolckholm University, Swedish Museum of Natural History, Stolckholm, Sweden.

Thatcher, V. (1991), Amazon fish parasites. Amazoniana, 11, 263-572.

Weis, M. L. C. (1983), Interpretação da idade e curva de crescimento do jundiá, Rhamdia quelen (Quoy and Gaimard, 1824) do banhado de Santa Catarina, RS. Ciênc. Nat., 5, 103-126.

Received: September 29, 2003; Revised: June 28, 2004; Accepted: November 17, 2004. 